\title{
The Relationship Between Daily Carbonhydrate and Fat Intake A long with Migraine
}

\author{
Günlük Karbonhidrat ve Yağ Alımı ile Migren Arasındaki İlişki Diyet \& Migren
}

${ }^{1}$ Ceyla Atac, ${ }^{1}$ Neslihan Eskut, ${ }^{2}$ Hasan Armagan Uysal

${ }^{1}$ University of HealthSciences, IzmirBozyakaEducationand Training Hospital,

Department of Neurology, Izmir Turkey

${ }^{2}$ Izmir University of Economics, MedicalparkHospital, Department of Neurology, Izmir Turkey

\section{Correspondence:}

Neslihan ESKUT

University of Health Sciences, Izmir Bozyaka Educationand Training Hospital, Department of Neurology, Izmir Turkey

e-mail:nespur@hotmail.com

\section{Abstract}

The pathophysiology of migraine is not fully understood. The trigeminovascular pathway activation, cortical spreading depression, vascula dysfunction, pro-inflammatory and oxidative states, and gut microbiota are investigated. In this study, we aimed to evaluate the relationship between diet and migraine disease characteristics of our patients. This study was conducted with episodic migraine without aura (n:30) and chronic migraine patients (n:30). Demographic data, body mass indexes (BMI), migraine characteristics were recorded from headache diaries. Food consumption were noted Daily from diet diaries. Total calorie intake and carbohydrate and fat amounts were calculated with an internet-based calorie calculator program. The mean age was $40.1 \pm 7.83$ years in chronic migraine group ( group 1 ), and $39.1 \pm 6.09$ years in group 2. The mean BMI of group 1 was significantly higher (respectively; $28.3 \pm 3.14$, and $24.9 \pm 3.29$ ). The mean duration of migraine was found longer in group 1 . The mean headache attack duration was $29.9 \pm 21.85$ hours in group 1 , and $29.6 \pm 22.4$ was in episodic migraine without aura group (group 2). There was no significant difference between both groups in terms of headache attack duration. Average Daily carbohydrate intake is $178.53 \pm 44.86$ grams in group 1, and $171.42 \pm 50.67$ grams in group 2 . The mean Daily fat intake was $58.01 \pm 13.65$ grams in group 1 and $56.62 \pm 7.51$ grams in group 2. No significant difference was found between the groups in terms of Daily calorie, mean Daily fat and, average carbohydrate intake. In our study, we did not find difference in food intake between groups, but BMI of the chronic migraine group were higher. The role of diet on the migraine pathophysiology is still under investigation. An integrative approach to migraine patients by reviewing their diet will help to understand the pathophysiology of migraine, increase the quality of life of patients and prevent unnecessary drug usage.

Keywords: Episodic migraine; chronicmigraine; body massindex; diet; calorieintake; carbohydrateintake; Fatintake

Migren patofizyolojisi hala tam anlașılamamıștır. Trigeminovasküler yolak aktivasyonu, kortikal yayılan depresyon, vasküler disfonksiyon yanında proinflamatuar ve oksidatif durum,ve barsak mikrobiatası incelenmektedir. Bu çalışmada diyet özellikleriyle, migrenin hastalık karakteristikleri arasında bir ilişki olup olmadığını araştırmayı amaçladık. Bu çalışma kronik migren (grup 1) (n:30) ve epizodik aurasız migren ( grup 2) (n:30) hastalarıyla yürütüldü. Demografik bilgiler, vücut kitle indeksi (VKİ), migren hastalık özellikleri baş ağrısı günlüklerinden kaydedildi. Hastalar bir ay boyunca tükettikleri gıdaların günlügünü tuttular. Alınan günlük ortalama kalori, karbonhidrat ve yas̆

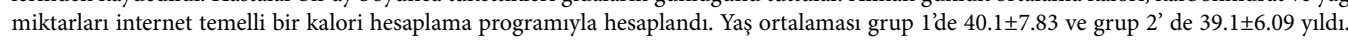

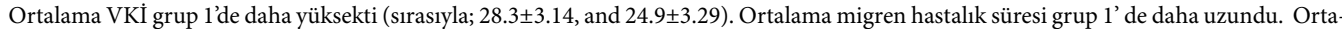

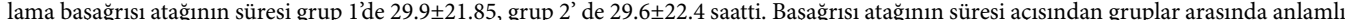
fark yoktu. Günlük ortalama karbonhidrat alımı grup l'de 178.53 \pm 44.86 , grup 2' de $171.42 \pm 50.67$ gramdı. Günlük ortalama yağ alımı grup

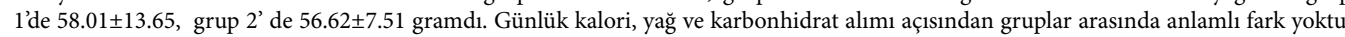
Çalışmamızda gıda alımları açısından gruplar arasında fark bulmadık fakat VKİ kronik migren grubunda daha yüksekti. Diyetin migren patofizyolojisindeki rolü hala araștırılmaktadır. Migren hastalarındaki diyetlerinin de gözden geçirilerek bütüncül bir yaklașım, migren patofizyolojisinin anlaşılmasına, hastaların yaşam kalitesinin arttırılmasına ve gereksiz ilaç kullanılmasının önlenmesine yardımcı olacaktır.

Anahtar Kelimeler: Epizodikmigren; kronikmigren; vücut kitle indeksi; diyet; kalorialımı; karbonhidratalımı; yağalımı 


\section{Introduction}

Migraine is a chronic neurological disease which genetic and environmental factors have role in it's development. Life time prevalence of migraine is estimated to be $14 \%$ of adults (1). The pathophysiology of migraine is still not fully understood. The roles of trigeminovascular pathway activation, cortical spreading depression, vascular dysfunction, pro-inflammatory and oxidative states, and gut microbiota are investigated. Taking into account all these factors that are suggested to play a role in the pathophysiology of migraine and an integrative approach to the treatment of migraine patients increases the quality of life and treatment success of patients (2). Therefore, it is becoming increasingly important to review and adjust the diets of patients.

In order to contribute to the treatment of migraine, approaches such as losing weight, removing foods that trigger migraine attacks from the diet, restricting calories, carbohydrates and fats, or adding supplements such as omega-3 and vitamin D to the diet are suggested (2). The effect of these treatment approaches on treatment investigated in limited number of studies $(3,4)$.

In this study, we planned to monitor the food intake behaviors of patients with episodic and chronic migraine for one month and investigate whether there is a relationship between average daily calorie intake, carbohydrate and fat intake and migraine disease duration, monthly average attack frequency and monthly average duration.

\section{Material and Methods}

This study was conducted with 30 patients with episodic migraine without aura (EAM) and 30 patients with chronic migraine (CM) who admitted to the Neurology outpatient clinic of University of Health Sciences, Izmir Bozyaka Education and Research Hospital, between February 2021, and July 2021.The patients' age, gender, duration of migraine disease, monthly average headache frequency, average headache duration, medications used in attacks and prophylaxis were obtained from the patients' headache diaries and medical records. The diagnosis of migraine was made according to the International Classification of Headache Disorders-3 criteria (5).

The height and weight of the patients were noted at the beginning of the study. Body mass indexes (BMI) were calculated (6). Neurological and systemic examinations were performed. The patients kept a diary of the foods they consumed for a month. Daily average calorie intake, carbohydrate and fat intake were calculated with an internet-based calorie calculator program.

Inclusion criteria of the patient group were to be between the ages of 18-55, to be diagnosed with episodic migraine without aura, and to be diagnosed with chronic migraine. Those with any chronic neurological or systemic disease other than migraine (diabetes mellitus, chronic kidney failure, thyroid dysfunction, malignancy, etc.), those who smoke, use alcohol, have any disease that may affect the sense of taste and smell, take antineoplastic or corticosteroid treatment, have pregnacy and the patients who could not keep a regular headache and food diary were excluded from the study. Informed constent form was taken from participants and the study was approved by local ethical committee (Reference number 2021/11, Date: 26/01/2021).

\section{Statistical analyses}

The obtained data were analyzed using the SPSS version 23 program. The normality of the data distribution was determined by the Shapiro-Wilk test. Mann-Whitney U t set was used because our data did not show normal distribution. Analysis results were presented as mean standard deviation (minimummaximum). $\quad \mathrm{p}<0.05$ were considered significant.

\section{Results}

Thirty patients were included in the chronic migraine group (group 1) and 30 patients in the episodic migraine group (group 2). The mean age of group 1 was $40.1 \pm 7.83$ (18-55), and the mean age of group 2 was 39.1 \pm 6.09 (33-54). No statistical difference between the two groups was found $(\mathrm{p}=0.358)$. Both patient groups were all females $(\mathrm{p}=1,000)$ (Table 1). 
The mean BMI of group 1 was $28.3 \pm 3.14$ (23.52-33.62), mean BMI of group 2 was $24.9 \pm 3.29$ (20.9-32.0). The mean BMI of group 1 was significantly higher than group 2 $(\mathrm{p}<0.001)$. The mean duration of migraine in group 1 was $20.3 \pm 7.81(5-40)$ years, and the mean duration of migraine in group 2 was $12.7 \pm 6.3(5-30)$ years, and there was a statistically significant difference between them $(\mathrm{p}<0.001)$. The mean monthly attack frequency of group 1 was $19.53 \pm 3.54$ (15-27) and the monthly mean attack frequency of group 2 was $5.06 \pm 3.06$ (1-12). There was a statistically significant difference when compared $(\mathrm{p}<0.001)$. The mean headache attack duration of group 1 was $29.9 \pm 21.85$ (672) hours, and the mean headache attack duration of group 2 was $29.6 \pm 22.4$ (6-72) hours. There was no significant difference between both groups $(p=0.068)$ (Table 1$)$.
Average daily calorie intake was $1546.83 \pm 169.45 \mathrm{kcal}$ (1350-1987) and, $1542.46 \pm 157.47 \mathrm{kcal}$ (1258-1725) in group 2 . No significant difference was found between groups with regard to average daily calorie intake $(p=0.155)$. Group 1 average daily carbohydrate intake is $178.53 \pm 44.86$ grams (75.16-235.39), group 2 average daily carbohydrate intake is $171.42 \pm 50.67$ grams (48.86-250.0). There was no difference between the two groups iwith regard to daily average carbohydrate intake $(p=0.274)$. The mean daily fat intake was $58.01 \pm 13.65$ grams (41.55-99.52) in group 1 and $56.62 \pm 7.51$ grams (42.52-75) in group 2. No significant difference was found between the groups in terms of mean daily fat intake $(p=0.918)$ (Table 1).

Table 1. Descriptive and clinical characteristics of groups

\begin{tabular}{|c|c|c|c|}
\hline & $\begin{array}{l}\text { Group } 1 \\
(\mathrm{n}: 30 / \text { Female }) \\
(\text { mean } \pm \text { SD })(\text { min-max })\end{array}$ & $\begin{array}{l}\text { Group } 2 \\
(\mathrm{n}: 30 / \text { Female }) \\
(\text { mean } \pm \text { SD })(\text { min-max })\end{array}$ & $p$ \\
\hline Age & $40.1 \pm 7.83(18-55)$ & $39.1 \pm 6.09(33-54)$ & 0.358 \\
\hline BMI(kg) & $28.3 \pm 3.14(23.52-33.62)$ & $24.9 \pm 3.29(20.9-32.0)$ & $<0.001$ \\
\hline $\begin{array}{c}\text { Duration of migrain } \\
\text { (years) }\end{array}$ & $20.3 \pm 7.81(5-40)$ & $12.7 \pm 6.3(5-30)$ & $<0.001$ \\
\hline $\begin{array}{l}\text { Attack frequency } \\
\text { (n/month) }\end{array}$ & $19.53 \pm 3.54(15-27)$ & $5.06 \pm 3.06(1-12)$ & $<0,001$ \\
\hline $\begin{array}{c}\text { Headache attack duration } \\
\text { (hours) }\end{array}$ & $29.9 \pm 21.85(6-72)$ & $29.6 \pm 22.4(6-72)$ & 0.068 \\
\hline Calorie intake (kcal/day) & $1546.83 \pm 169.45(1350-1987)$ & $1542.46 \pm 157.47(1258-1725)$ & 0.155 \\
\hline $\begin{array}{c}\text { Carbohydrate intake } \\
\text { (gram/day) }\end{array}$ & $178.53 \pm 44.86(75.16-235.39)$ & $171.42 \pm 50.67(48.86-250.0)$ & 0.274 \\
\hline fat intake (gram/day) & $58.01 \pm 13.65(41.55-99.52)$ & $56.62 \pm 7.51(42.52-75)$ & 0.918 \\
\hline
\end{tabular}

\section{Discussion and Conclusion}

In our study, the mean BMI of patients with CM was found to be higher than those with EM, in line with the publications reporting that obesity may be a risk factor for the chronicity of migraine. There was no significant difference between the daily calorie, carbohydrate and fat intake of the patients in both groups.

It has been suggested in the early 2000s that there may be a relationship between obesity 
and primary headaches. In a population-based prospective study in which obese individuals were followed for nearly one year, it was revealed that obese individuals have a 5-fold higher risk of developing chronic daily headaches compared to individuals with normal weight (7). In addition, there are many studies showing that obesity is a risk factor for the conversion from episodic migraine to chronic migraine (8-10). It was revealed that the frequency of headaches increases as BMI increases in a population-based study examining more than 30,000 migraineurs (11).

The relationship of obesity and migraine can be interpreted by some possible mechanisms. Studies conducted on individuals with obesity have found elevated levels of proinflammatory cytokines such as IL-1 $\beta$, IL-6, and TNF- $\alpha(12,13)$. These pro-inflammatory cytokines also increase in individuals with migraine during a migraine attack $(14,15)$. Persistent low-grade inflammatory status in obese individuals may trigger migraine attacks. It has also been shown that CGRP and substance $\mathrm{P}$, which play a role in triggering migraine attacks, increase in obese individuals and migraine patients $(16,17)$. In the light of these reports, it is suggested that obese individuals tend to have more frequent and severe migraine attacks. From another point of view, studies show that adiponectin levels secreted from adipocytes decrease during migraine attacks (18), and low adiponectin levels play a role in the development of obesity, atherosclerosis, and diabetes (19). In this case, it can be suggested that patients with chronic migraine who have frequent attacks have a predisposition to obesity.

In our study, we did not find a difference in food intake between episodic and chronic migraine groups, but BMI' $s$ of our chronic migraine group were higher. In the studies investigating the relationship of obesity and migraine, recording the weight of the patients in the episodic migraine period and comparing them with their weight in the chronic migraine period, simultaneously following the patients with food diaries may clarify whether the conversion from episodic migraine to chronic migraine is triggered by weight gain, or whether the weight of the patients changes from episodic migraine to chronic migraine.

Studies conducted with fat-restricted diets have reported a decrease in headache severity and frequency (20), and also, a decrease in the need to use attack medication (21). In another study, it was observed that adding omega-3 to the diet decreased the headache frequency (22). In a randomized controlled study on a carbohydrate-restricted diet, 350 migraine patients were divided into low glycemic index diet group (high fiber intake group) and prophylactic drug group. One month after dietary restriction was applied, the frequency of attacks decreased in both two groups (4). However, it has also been found that a lowcalorie diet with low carbohydrate and fat consumption has no effect on migraine treatment (23). On the other hand, Evans et al. Reported no difference between the diets of healthy women and women with migraine (24).

In our study, we did not find difference between daily calorie, carbohydrate and fat intake between patient groups. However, the follow-up period of the patients was limited to one month. The one-month follow-up period may not have been long enough to allow us to reveal the difference in food consumption between the two groups. In addition, when we examined the food diaries of our patients, we noticed that they consumed high-calorie foods in the first days, but they turned to low-calorie foods in the following days. The fact that our patients took note of the foods they consumed may have changed their food consumption behavior and led them to prefer foods with less calories. In addition, considering the amount of omega-3 intake and the glycemic index of carbohydrates can also help to show the effects of diet on migraine.

The role of diet on the migraine pathophysiology is still under investigation. Diet has an effect on the colonization, maturation and stabilization of the intestinal flora. Studies in animals and humans have shown that the composition of human intestinal flora changes within 4 days after consuming a specific diet. High-fat diets reduce the amount of bacteria synthesizing short-chain fatty acids (25). Reducing the 
amount of short-chain fatty acids increases intestinal permeability. The participation of pro-inflammatory cytokines such as IL-1 beta and TNF alpha released from the intestines into the circulation increases. The release of pro-inflammatory cytokines may trigger migraine pain through stimulation of nociceptive responses in the trigeminal pathway. Gut microbiota changes (dysbiosis) affect the normal breakdown of nutrients (tryptophan metabolism), barrier permeability, and ultimately affect communication pathways by affecting mucosal immune and endocrine cells, resulting in increased gut peptides ( $\uparrow$ CGPR), cytokines ( $\uparrow$ IL-10) produced by some agents, and hormones $(\downarrow 5$ HT) are reported to cause abnormal release. It is suggested that increased cytokine and CGRP levels, as well as decreased 5-HT levels, trigger and perpetuate migraine attacks by modulating the vasodilator responses of dural vessels $(25,26)$

It is reported that alterations in the gut microbiota according to dietary changes and

\section{REFERENCES}

1. Cámara-Lemarroy CR, Rodriguez-Gutierrez R, Monreal-Robles R, Marfil-Rivera A. Gastrointestinal disorders associated with migraine: A comprehensive review. World $J$ Gastroenterol. 2016;22:8149-60.

2. Razeghi Jahromi S, Ghorbani Z, Martelletti P, Lampl C, Togha M. School of Advanced Studies of the European Headache Federation (EHFSAS). Association of diet and headache. $J$ Headache Pain. 2019;20:106.

3. Di Lorenzo C, Coppola G, Sirianni G, Pierelli F. Short term improvement of migraine headaches during ketogenic diet: a prospective observational study in a dietician clinical setting. $J$ Headache Pain. 2013;14:P219.

4. Evcili G, Utku U, Öğün MN, Özdemir G. Early and long period follow-up results of low glycemic index diet for migraine prophylaxis. Agrl. 2018;30:8-11.

5. Headache Classification Committee of the International Headache Society (IHS) The International Classification of Headache Disorders, 3rd edition. Cephalalgia. 2018;38:1211.

6. Deurenberg P, Weststrate JA, Seidell JC. Body mass index as a measure of body fatness: ageand sex-specific prediction formulas. Br J Nutr. 1991;65:105-14. decrease of possibly inflammation can have a significant effect on migraine. Migraine may be improved by encouraging intake of proper consumption of fiber, carbonhydrates with low glycemic-index, vitamin D, and omega-3 fatty acids, low-fat vegan and gluten-free food, probiotics (27).

Our study was conducted with a limited patient group and a follow-up period of one month. Future studies needed be planned in larger patient groups, with longer follow-up periods, and by noting the weight change dates of the patients, the glycemic index of the foods they consume, and the omega- 3 intake.

In conclusion, studies have shown that diet affects the pathophysiology of migraine at many points. An integrative approach to migraine patients by reviewing their diet will help to understand the pathophysiology of migraine, increase the quality of life of patients and prevent unnecessary drug usage. We think that it will be very useful to monitor our patients with headache diaries as well as diet diaries.

7. Scher A, Stewart W, Ricci J, Lipton R. Factors associated with the onset and remission of chronic daily headache in a population-based study. Pain. 2003;106:81-9.

8. Bigal ME, Liberman JN, Lipton RB. Obesity and migraine: a population study. Neurology. 2006;66:545-50.

9. Bigal ME, Tsang A, Loder E, Serrano D, Reed ML, Lipton RB. Body mass index and episodic headaches: a population-based study. Arch Intern Med. 2007;167:1964-70.

10. Peterlin BL, Rosso AL, Rapoport AM, Scher AI. Obesity and migraine: the effect of age, gender and adipose tissue distribution. Headache. 2010;50:52-62.

11. Kristoffersen ES, Børte S, Hagen K, Zwart JA, Winsvold BS. Migraine, obesity and body fat distribution - a population-based study. $J$ Headache Pain. 2020;21:97.

12. Goyal R, Faizy AF, Siddiqui SS, Singhai M. Evaluation of TNF- $\alpha$ and IL-6 levels in obese and non-obese diabetics: pre- and Postinsulin effects. N Am J Med Sci. 2012;4:180-4.

13. Popko K, Gorska E, Stelmaszczyk-Emmel A, Plywaczewski R, Stoklosa A, Gorecka D, et al. Proinflammatory cytokines Il- 6 and TNF- $\alpha$ and the development of inflammation in obese 
subjects. Euro J Med Res. 2010;15(Suppl 2):120-2.

14. Sarchielli P, Alberti A, Baldi A, Coppola F, Rossi C, Pierguidi L, et al. Proinflammatory cytokines, adhesion molecules, and lymphocyte integrin expression in the internal jugular blood of migraine patients without aura assessed ictally. Headache. 2006;46:200-7.

15. Fidan I, Yuksel S, Ymir T, Irkec C, Aksakal FN. The importance of cytokines, chemokines and nitric oxide in pathophysiology of migraine. $J$ Neuroimmunol. 2006;171:184-8.

16. Bond DS, Roth J, Nash JM, Wing RR. Migraine and obesity: epidemiology, possible mechanisms and the potential role of weight loss treatment. Obes Rev. 2011;12:e362-ee71.

17. Zelissen PM, Koppeschaar HP, Lips CJ, Hackeng WH. Calcitonin gene-related peptide in human obesity. Peptides. 1991;12:861-3.

18. Peterlin BL, Sacco S, Bernecker C, Scher AI. Adipokines and migraine: a systematic review. Headache. 2016;56:622-44.

19. Achari AE, Jain SK. Adiponectin, a therapeutic target for obesity, diabetes, and endothelial dysfunction. Int J Mol Sci. 2017;18:1321.

20. Ferrara L, Pacioni D, Di Fronzo V, Russo B, Speranza E, Carlino V et al. Low-lipid diet reduces frequency and severity of acute migraine attacks. Nutr Metab Cardiovasc Dis. 2015; 25:370-5

21. Bunner AE, Agarwal U, Gonzales JF, Valente F, Barnard ND. Nutrition intervention for migraine: a randomized crossover trial. J Headache Pain. 2014;15:69.

22. Abdolahi M, Tafakhori A, Togha M, Okhovat AA, Siassi F, Eshraghian MR et al. The synergistic effects of $\omega-3$ fatty acids and nanocurcumin supplementation on tumor necrosis factor (TNF)- $\alpha$ gene expression and serum level in migraine patients. Immunogenetics. 2017;69:371-8.

23. Di Lorenzo C, Coppola G, Sirianni G, Pierelli F. Short term improvement of migraine headaches during ketogenic diet: a prospective observational study in a dietician clinical setting. J Headache Pain.2013;14:P219.

24. Evans EW, Lipton RB, Peterlin BL, Raynor HA, Thomas JG, O'Leary KC, et al. Dietary intake patterns and diet quality in a nationally representative sample of women with and without severe headache or migraine. Headache. 2015;55:550-61.

25. Zhang M, Yang XJ. Effects of a high fat diet on intestinal microbiota and gastrointestinal diseases. World J Gastroenterol. 2016;22:89058909.

26. Agus, A, Planchais, J, Sokol, H. Gut microbiota regulation of tryptophan metabolism in health and disease. Cell Host Microbe. 2018;23:716-24

27. Gazerani P. Migraine and Diet. Nutrients. 2020;12:1658. 